\title{
Contingent Convertibles and their Impacts on the Optimization of the Capital Structure of Brazilian Banks Under Basel III*
}

\author{
Karina Cyganczuk Goes \\ Fundação Getúlio Vargas, Escola de Administração de Empresas de São Paulo, Departamento de Pós-Graduação, São.Paulo, SP, Brazil
}

\section{Hsia Hua Sheng}

Fundação Getúlio Vargas, Escola de Administração de Empresas de São Paulo, Departamento de Contabilidade, Finanças e Controle, São Paulo, SP, Brazil

Universidade Federal de São Paulo, Escola Paulista de Política, Economia e Negócios, Programa de Graduação, Osasco, SP, Brazil

\section{ABSTRACT}

Banks around the world maintain excess regulatory capital, whether to minimize capitalization costs or to mitigate risks of financial difficulties. However, it was only after the financial crisis of 2008 that the quality of capital gained greater importance among international regulators, through the Third Basel Accord (Basel III), which suggested a capital structure formed of the new equity and debt hybrid instruments, that is, Contingent Convertibles ( $\mathrm{CoCos})$, which have the main goal of recapitalizing banks automatically when they show signs of financial difficulties. Using the continuous-time structural model developed by Koziol and Lawrenz (2012), with December 2013 as a reference, this paper analyzes the capital structure of the 10 biggest Brazilian banks in terms of total assets, comparing their current structures - with only subordinated debts - with the structure proposed in Basel III, composed solely of contingent convertibles, with a view to verifying the influence of CoCos in banks' risks and evaluating the effectiveness of this Basel III recommendation. Through the evidence obtained using the model mentioned, this paper's main contribution is in demonstrating that the use of CoCos would optimize the capital structure of banks under the restrictions of Basel III, considering these are effective. If not, the automatic recapitalization of these instruments could be used for shareholders' own benefit, thus increasing the likelihood of banks experiencing financial difficulties, which could cause a new financial crisis, like that which occurred in 2008.

Keywords: contingent convertibles, regulatory capital, Basel III. 


\section{INTRODUCTION}

In 2007, the equity of the 20 biggest banks in the United States - that is, almost two thirds of US banking assets was $11.7 \%$ of risk-weighted assets (RWAs), with $8 \%$ being the minimum suggested by Basel II. Nevertheless, many failed or required government assistance, primarily as a result of them being essentially capitalized in subordinated debts, to which it is provided capital to protect depositors, however also allows an increase in banks' leverage, canceling part or all of the effect of reducing the likelihood of financial difficulties (Pennacchi, 2010) and showing that the regulation of capital in place at the time was extremely fragile (Kuritzkes \& Scott, 2009; Calomiris \& Herring, 2011).

The increase in leverage exacerbates moral risk and this is difficult to identify within the financial system, given that financial difficulties can, in fact, be caused by external and unpredictable factors, and not necessarily by reckless behavior on the part of banks (Dam \& Koetter, 2012). Because of this, governments tend to assist banks with financial difficulties, especially those with systemic importance in the local or global economy, in order to avoid new crises. In turn, banks, aware of this implicit "guarantee", tend to assume more risk in order to increase their returns; this is the so called "too big to fail" effect. Similarly, investors, in perceiving this "too big to fail" effect, migrate their resources to big banks, believing that they are safer, given the implicit government protection (Oliveira, Schiozer, \& Barros, 2015). This practice makes the position of governments facing bank bankruptcies even more difficult, since the option of not saving one big bank could shatter confidence in the entire banking system, with grave consequences for economic activity.

With a view to alleviating these problems, the Basel Committee on Banking Supervision (BCBS), through Basel III, proposed new recommendations for the capital structure of banks, in order to make it more effective in absorbing losses and initially transferring the entire onus of the recovery of banks to investors and owners, in an attempt to avoid this responsibility falling on the government and, consequently, on society. Basel III brings to capital structure a new equity and debt hybrid instrument, the CoCo, originally proposed by Flannery (2005); it is composed of debt instruments, which are compulsorily perpetual and convertible into shares in banks when they suffer financial difficulties. Before conversion, the CoCo behaves as a common subordinated debt, paying a periodic coupon. In its contract, a debt conversion trigger is defined, which could be an accounting measurement (Basel III, 2010; Glasserman \& Nouri, 2010), or one involving the market value of banks' shares (Flannery, 2005; Calomiris \& Herring, 2011), among other methodologies. Thus, once a bank exhibits financial difficulties and touches the minimum threshold defined in the contract, the trigger is activated and part or the entire principal invested is automatically transformed into equity for the bank, with the investor, in turn, receiving the principal in shares in the bank. Or still, in some cases such as that of Banco do Brasil, the debt is converted into equity for the bank, and the principal lost for the investor; the big advantage of CoCos is automatic "recapitalization" at a low cost.

Since the crisis of 2007 and new regulations, many studies have been developed regarding the capital structure of banks. Albul, Jaffee, and Tchistyi (2010) elaborated a financial model that allows the capital structure of banks with CoCos and subordinated debt to be analyzed, applying different types of restrictions. These authors concluded that CoCos, with the correct risk incentive restrictions and in contrast to subordinated debts, protect the shareholder equity of banks against financial crises, as well as offering greater tax benefits. Barucci and Del Viva (2012) showed that $\mathrm{CoCos}$ are useful instruments for dealing with the negative effects of the phenomenon of risk displacement from banks to investors, at the heart of the 2007 crisis. They theoretically analyzed the capital structure of banks which issue subordinated debt and CoCos with conversion dependent on macroeconomic (counter-cyclical) conditions, and in doing so concluded that CoCos are more efficient that subordinated debts with regards to risk incentive restrictions, since, despite leaving banks slightly more leveraged, a large part of risk is absorbed by the holders of CoCos and not by banks themselves. Koziol and Lawrenz (2012) developed a time-continuous structural model, which determines - over time - the optimum capital structure for a bank with subordinated debts and CoCos. These authors showed that CoCos have a beneficial impact on the structure of banks, maximizing their value, as long as risk incentive and displacement restrictions are well defined. If not, they can substantially increase the likelihood of financial difficulties. Guidara, Soumaré, and Tchana (2013) analyzed the relationship between excess regulatory capital and the economic cycles of the six biggest Canadian banks between 1982 and 2010, using a simultaneous equations model based on risk and equity variables calculated by the banks; they concluded that they are well capitalized, given that they exceed the minimum regulatory requirements by $5.09 \%$ and the leverage ratio by $0.49 \%$, with these being some of the reasons why they resisted the crisis of 2007 well. Moreover, Canadian banks have conservative mortgage practices, are not totally financed by the monetary market, and maintain high levels of liquidity.

Thus, the aim of this paper is to verify the influence of using CoCos on banks' risks, evaluating the effectiveness of this Basel III recommendation. Capitalization with CoCos versus the use of subordinated debts was also evaluated. The main study hypothesis is that the use of CoCos would optimize the capital structure of banks under the restriction of Basel III.

The Koziol and Lawrenz (2012) model was applied to the structure of the 10 biggest Brazilian banks in terms of total assets $(75.1 \%$ of the Brazilian National Financial System, or SFN, using the initials in Portuguese) using records from 
2009 to 2013 . This allowed the optimal capital structure for these banks to be estimated for December 2013 (4Q2013) and each bank in the sample to be evaluated comparatively, with only subordinated debts and when these are totally substituted by CoCos. Furthermore, the model also allows the behavior of banks in relation to CoCos to be evaluated, when there are no restrictive regulations for the taking or displacement of risk. The evidence obtained suggests that, according to the model, the banks in the sample would be better capitalized if their capital structures were composed solely of CoCos, when there is regulation restricting the taking and displacement of risk. However, in the absence of these regulations, the banks would exhibit greater risk with CoCos than with subordinated debts.

This paper, as far as is known, is the first to evaluate the use of CoCos in comparison with subordinated debts in capitalizing Brazilian banks. This paper contributes not only to the decisions taken by managers when composing their capital structures, but also in examining the effectiveness of regulators recommending Basel III.

\section{BIBLIOGRAPHIC REVIEW}

The idea that regulatory bodies distort banks' incentives, limiting their leverage through equity, may have been true until the 80s; after this time, banks came to raise and maintain excess capital, due to an own incentive of protecting themselves against risks. Peura and Keppo (2005) call this excess capital "hedging" against breaches of minimum capital, and estimate some average percentage values for excess capital of between $2.4 \%$ and $3.5 \%$ above the regulatory minimum. Studies by Teixeira, Silva, Fernandes, and Alves (2014), and VanHoose (2007), showed that banks maintain excess capital in order to avoid emergency recapitalization costs.

Flannery and Rangan (2008), in a study regarding big banks in the United States in the 90s, provided evidence of post-recession capital growth, with banks accumulating, on average, $75 \%$ of capital above the regulatory minimum, in a rational reply on the part of the banking market to the measure of withdrawing implicit government guarantees.
In Basel I, the minimum regulatory capital recommended was $4 \%$ of level I and $8 \%$ in total, but the Federal Deposit Insurance Corporation Improvement Act (FDICIA) itself specified that banks with level I above 5\% and with level II above $10 \%$ were considered "well capitalized"; that is, there was not only an indirect government incentive to maintain excess capital but also the concept that this guaranteed good capitalization of banks.

Brazil adhered to the Basel regulations in 1994 and, in 1997, with the stabilization of the Real Plan and of the Brazilian economy, the Brazilian Central Bank, or BACEN, using the initials in Portuguese, opted for a more conservative position in relation to the Basel ratio, raising the minimum capital required from $8 \%$ to $11 \%$ of RWA, in order to have an "excess of regulated capital". Even still, Brazilian banks maintained excess capital of, on average, 4.5 percentage points above the minimum required, as can be observed in Figure 1.

\section{Historic Record of Basel Ratio in the SFN}

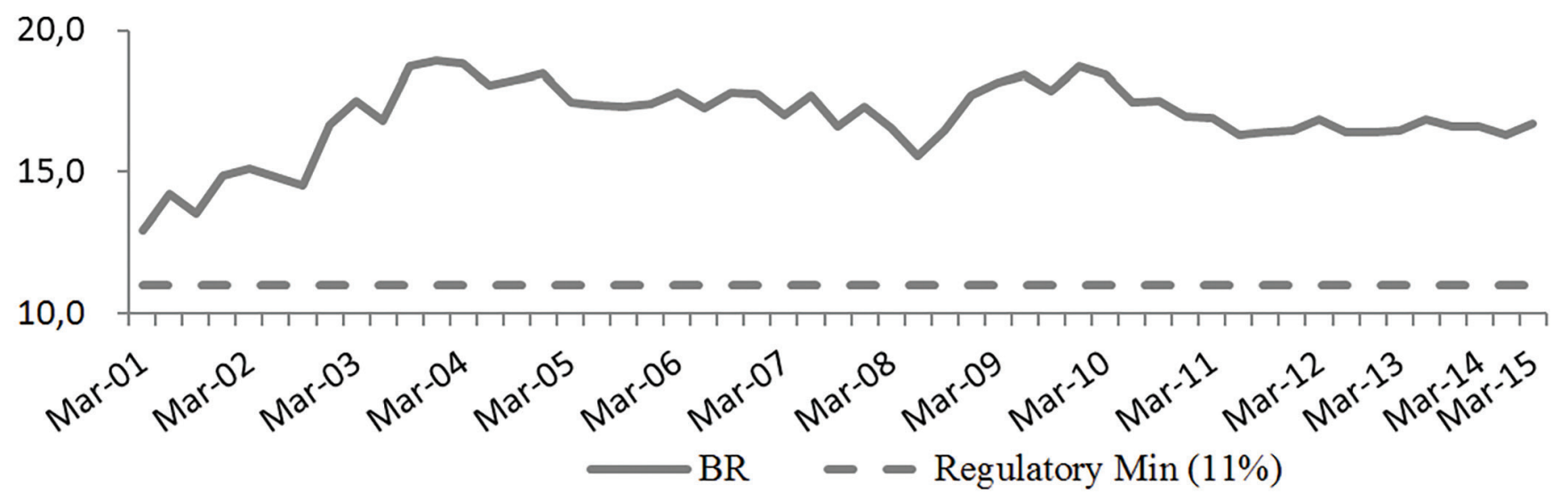

Figure $1 \quad$ Average Basel Ratio of banks in the SFN.

Source: BACEN Financial Stability Report. Developed by the authors. 
With the new Basel III Accord requirements, the percentage of capital comes to be $11 \%$, and so Brazil would already comply; however, it is the changes in the structure of this capital that is, in fact, of interest to the scope of this paper. Regarding capital structure, level I comes to be composed of portions of core capital (share capital, retained earnings, and reserves), additional capital (CoCos), and an amount that is complementary to the minimum regulatory requirements (also composed of share capital and CoCos, accumulated during favorable periods in economic cycles and used in moments of stress, or rather, during the operations of institutions). Level II capital is composed of elements that are able to absorb losses in the case of it becoming unfeasible for institutions to operate, that is, subordinated debts. The debt instruments have a maximum limit of participation in each portion of capital: CoCos in additional level I capital - up to $15 \%$ of total level I, and subordinated debts - up to $50 \%$ of total level I. Moreover, the minimum threshold defined for the conversion of CoCos is $4.5 \%$ of RWA.

With a view to evaluating how much the issuance of CoCos affects banks' values, Pennacchi (2010) compares risk incentives between banks that issue CoCos and those that only issue subordinated debts and shows that the benefit of CoCos may be offset if a bank has the incentive to increase its risk in search of higher returns, given that the conversion of the principal into capital transfers the original shareholders' risk to investors in these securities, and the incentives for displacement to riskier assets increases as the equity of the bank decreases. However, when the conversion limit is relatively elevated in relation to own equity, that is, when the original shareholders run the risk of losing their current positions to new shareholders, given the conversion of CoCos, these come to restrict of the incentives for risk. Calomiris and Herring (2011) propose a conversion amount for CoCos relative to net equity, and not restricted to the $15 \%$ of the total of level I, in order to mitigate delays in the recognition of losses through combinations of accounting values, since all loss that is "window dressed" and transformed into net equity would be covered by a contingent convertible and, the greater this loss, the greater the value of conversion and the lower the participation of original shareholders in the company total. Sundersan and Wang (2014) propose that the conversion of CoCos should be based on the market equilibrium. Thus, CoCos should be publicly tradable, with mandatory conversion based on observable market value, or rather, on informative criteria, that is difficult to manipulate and independent from regulator intervention, making the market price an indicator of banks' financial difficulties. Since the CoCo is converted and its owners become part of bank equity, the equilibrium is in the preference for conversion on the part of the owners of CoCos as opposed to preference for non conversion on the part of the shareholders. This way, the big question regarding the efficiency of the new rules proposed by Basel III is in the CoCo conversion trigger, and not in the fact that they are more efficient instruments than subordinated debts for mitigating problems of moral risk and "too big to fail".

In Brazil, the new Basel III rules will be implemented gradually over the course of six years (2014 to 2019), and, in this context, Sobreira and Silva (2012) analyzed the potential impacts of these rules on Brazilian banks. From a sample of 92 Brazilian public and private banks, the authors apply the Central Bank of Brazil's rules and observe that the main private banks have a comfortable position in relation to the minimum Basel III requirements; public banks, in turn, will have to increase their equity through an increase in share capital or through issuing debt securities.

Also with a view to the capitalization of Brazilian banks, this paper stands apart from others, since its focus is on the capitalization efficiency of the instruments that compose the capital structure of banks, when there are restrictive regulations for risk incentive or displacement, as well as the systemic risk of each of these instruments when these regulations are not in place.

\section{METHODOLOGICAL PROCEDURES}

Among the different models regarding company capital structure (Bhattacharya, Plank, Strobl, \& Zechner, 2002; Decamps, Rochet, \& Roger, 2004; among others), the Koziol and Lawrenz (2012) model was chosen, primarily for being a model developed for commercial banks, a characteristic that avoids potential adaptations necessary for models intended for companies in general. The second reason is that the model is current and post Basel III, and takes into account the characteristics defined by regulation for CoCos. Finally, the variables that are necessary for the model are public or can be estimated with public data for banks; Banco do Brasil (BB) will be used to present the model.

As a hypothesis, proposals 1, 2, and 3 of the model will be empirically verified.

\subsection{Optimal capital under BACEN and Basel III Regulations}

The model projects bank cash flow based on the historic record, using the stochastic differential equation 1.

$$
d x_{t}=\mu x_{t} d t+\sigma x_{t} d z_{t}
$$


in which constants $\mu$ and $\sigma$ represent, respectively, return and total volatility of cash flows. $x t$ are projected cash flows, represented by Earnings Before Interest and Income Tax (EBIT); in period $\mathrm{t}$ and $z_{t}$ it is a standard Wiener process which, through the Geometric Brownian motion, generates random cash flows. For each cash flow generated, the model estimates an optimal capital structure, however, our interest here lies solely in one estimate, that for 4Q2013, that is, $\mathrm{t}$ is equal to 1 .

Summing the interest paid by subordinated debts, equity and debt hybrid instruments, deposits, and taxation expenses (PIS, COFINS and ISS), the EBIT for BB will be:

Table 1

$B B$ Income statement

\begin{tabular}{cccccc}
\hline $\begin{array}{c}\text { INCOME STATEMENT } \\
\text { (R\$ bn) }\end{array}$ & $\begin{array}{c}\text { Result Before Tax } \\
\text { on Profits }\end{array}$ & $\begin{array}{c}\text { Other tax } \\
\text { expenses }\end{array}$ & $\begin{array}{c}\text { Interest paid on } \\
\text { subordinated } \\
\text { debts }\end{array}$ & $\begin{array}{c}\text { Interest paid } \\
\text { on contingent } \\
\text { convertibles }\end{array}$ & $\begin{array}{c}\text { Interest paid on } \\
\text { deposits }\end{array}$ \\
\hline $\mathbf{4 Q 1 3}$ & 4,160 & 1,244 & 2,387 & 1,451 & 16,236 \\
\hline
\end{tabular}

Source: Spreadsheet of historical series for 4Q2013 - Available from: <http://www.bb.com.br/portalbb/page206,136,145,0,0,1,8.bb>. Developed by the authors.

A 5-year (2009 to 2013) quarterly record of EBIT is used, in which $\mu$ is calculated by the average of returns of EBITs and $\sigma$ is the standard deviation in the series of calculated $\mu$ ' s. For BB we have: $\mu=0.01$ and $\sigma=0.11$. The threshold $(\xi)$ is the minimum value of cash flow that the bank can reach, from which it begins suffering financial difficulties. The Equation 2 defines this threshold relates the level of bank debt $(\pi)$ and a constant $\phi$ which represents the regulatory restriction for minimum capital.

$$
\xi(\pi)=\phi \pi
$$

The level of debt $\pi$ is the sum of the coupons and interest paid by the bank, which may be subordinated debt coupons (b), CoCo coupons (c) or interest on deposits (d), so we have Equation 3.

$$
\pi=d+b+c
$$

To estimate constant $\phi$, the Bank and Lawrenz (2010) approach will be used, which relates required reference equi- ty (RRE) - regulatory minimum of $11 \%$ of RWA - with the bank's current reference equity (RE), as shown in Equation 4.

$$
\phi=\frac{\mathrm{RRE}}{\mathrm{RE}}
$$

For $\phi>0$, if $\phi=1$, the bank exhibits evidence of financial difficulties, since its $\mathrm{RE}$ has reached the minimum regulatory limit defined by BACEN; if $\phi>1$, the bank has strict financial restrictions, even if its current cash flow exceeds the payment of interest; and if $\phi<1$, it is assumed that the bank is able to raise new capital to avoid insolvency, even if its current cash flows are lower than the total payment of interest. In order to estimate the parameters presented, data from BB's balance sheet will be used: 
Table $2 \quad$ Data from BB's balance sheet

\begin{tabular}{ccccccccccccccccccc}
\hline Date & $\mathbf{X t}$ & $\mathbf{d}$ & $\mathbf{b}$ & $\mathbf{c}$ & $\boldsymbol{\pi}$ & $\mathbf{A}$ & $\mathbf{L}$ & NE & $\mathbf{C}$ & $\mathbf{B}$ & $\mathbf{D}$ & RWA & BR & LIRE & LIIRE & RE & RRE \\
\hline $4 \mathrm{Q} 13$ & 25,478 & 16,236 & 2,387 & 1,451 & 20,074 & $1,303,915$ & $1,231,690$ & 72,225 & 39,404 & 32,519 & 491,013 & 813,623 & 14.53 & 85,501 & 32,733 & 118,234 & 89,499 \\
\hline
\end{tabular}

Note. $\mathrm{Xt}$ - Cash flow; $\mathrm{d}$ - total interest paid on deposits; $\mathrm{b}$ - total interest paid on subordinated debts; $\mathrm{c}$ - total interest paid on CoCos; $\pi$ - total interest paid by the bank; A - total assets; L - total liabilities; NE - net equity; C - amount of CoCos; B - amount of subordinated debts; D - amount of deposits; RWA - total risk weighted assets; BR - Basel ratio; LIRE - Level I RE; LIIRE - Level II RE.

Source: Spreadsheet of historic series from 4Q2013 - Available from: <http://www.bb.com.br/portalbb/page206,136,145,0,0,1,8.bb>. Developed by the authors

The constant $\phi$ for $4 \mathrm{Q} 2013$ for $\mathrm{BB}$ is $76 \%$ and the level of debt $\pi=\mathrm{R} \$ 20,074 \mathrm{bn}$, therefore, the threshold is $\xi(\pi)=\mathrm{R} \$$ $15,195 \mathrm{bn}$. The model takes exogenous deposits into account, and thus, the choice variables for capital structure optimization will be interest on subordinated debts (b) and interest on CoCos (c). Net equity is estimated by $\left(S_{t}\right)$, as shown in Equation 5.

$$
S_{t}=(1-\tau)\left(\left(\frac{x_{t}}{r-\mu}-\frac{\pi}{r}\right)-\left(\frac{\xi}{r-\mu}-\frac{\pi}{r}\right)\left(\frac{x_{t}}{\xi}\right)^{\beta}\right)
$$

in which $\tau$ is the corporate income tax, which has a value of $\tau=0.40$ and is defined by BACEN; $r$ is the interest free rate, for which the SELIC rate from the last working day of 2013 was used, $r=10.4 \%$. The amount $\left(\frac{x_{t}}{\xi}\right)^{\beta}$ is the discount factor weighted by its probability, given by Equation 6.

$$
\beta=-\frac{\left(\mu-\frac{\sigma^{2}}{2}+\sqrt{2 r \sigma^{2}+\left(\mu-\frac{\sigma^{2}}{2}\right)^{2}}\right)}{\sigma^{2}}
$$

For ease, the Koziol and Lawrenz (2012) notation will be adopted as shown in equations 7 and 8.

$$
\begin{gathered}
\mathcal{V}(y, \pi)=(1-\tau)\left(\frac{y}{r-\mu}-\frac{\pi}{r}\right) \\
\mathcal{D}\left(y, y^{\prime}\right)=\left(\frac{y}{y^{\prime}}\right)^{\beta}
\end{gathered}
$$

Thus, the net equity equation is:

$$
S_{t}=\mathcal{V}\left(x_{t}, \pi\right)-\mathcal{V}(\xi, \pi) \mathcal{D}\left(x_{t}, \xi\right)
$$

For $\mathrm{BB}$, the values are: $\beta=-4.6869, \mathrm{~V}\left(\mathrm{x}_{\mathrm{t}}, \pi\right)=43,600$, The model assumes that deposits $(\mathrm{d})$ are insured and that $\mathrm{V}(\xi, \pi)=-14,998, \mathrm{D}\left(\mathrm{x}_{\mathrm{t}} \xi\right)=0.1162$ and $\mathrm{S}_{\mathrm{t}}=\mathrm{R} \$ 45,342 \mathrm{bn}$. banks must pay an insurance premium given by:

$$
\begin{gathered}
I_{t}=\max \left\{\frac{d}{r}-\frac{\lambda}{r-\mu} \xi, 0\right\} \mathcal{D}\left(x_{t}, \xi\right) \\
\lambda=(1-\alpha) *(1-\tau)
\end{gathered}
$$


in which $\lambda$ is the value of the percentage of bank liquidation, at the moment this reaches the regulatory minimum, $\alpha$ is the cost of bankruptcy which, according to an estimate by Andrade and Kaplan (1998), presented in a study regarding highly leveraged companies that suffered financial difficulties between 1980 and 1989, is between $10 \%$ and $20 \%$ of a company's value. These values are estimated by the di-

$$
\mathrm{Dt}=\frac{\mathrm{d}}{\mathrm{r}}
$$

And for BB: $\mathrm{Dt}=156,112 \mathrm{bn}$.

The current BACEN regulation allows banks to have both debts in their capital structure - that is, subordinated debts and CoCos; however, the model used only allows the bank's endogenous debt to be one of the two types. Thus, the bank's optimal debt in subordinated debts is estimated and the same value in CoCos is considered, making it feasible to compare the two fference between the value of total equity before bankruptcy and total equity paid in during bankruptcy. For the model, the average of these values, $\alpha=15 \%$, will be used. Thus, $\lambda=0.5100$ and $I_{t}=R \$ 8,185 b n$. Since deposits are insured, they become free of risk; this way, by discounting future payments by the risk free rate, the aggregate deposit value will be:

$$
b^{*}=\underset{b}{\operatorname{argmax}}\left\{S_{t}^{b}+B_{t}+D-I\right\}
$$

The bank's value is given by:

$$
V_{t}^{b}=S_{t}^{b}+B_{t}+D-I_{t}
$$

in which $B_{t}$ is the amount in subordinated debts and $D$ tion $\xi_{b}=\phi(d+b)$, the first derivative of $V_{t}^{b}$ with relati on is the amount in deposit and with the general restric- to $\mathrm{b}$ is:

$$
\frac{\partial V_{t}^{b}}{\partial b}=\frac{\tau}{r}-\frac{\zeta}{r} \mathcal{D}\left(x_{t}, \xi_{b}\right)
$$

in which

$$
\zeta=\frac{(1-\beta)(r-\mu) \tau+\phi r((1-\tau)-\lambda)}{r-\mu}
$$

Resolving the first order condition, we have the optimal debt:

$$
b^{*}=\frac{x_{t}}{\phi}\left(\frac{\tau}{\zeta}\right)^{\beta}-d
$$


As for $\mathrm{BB}, \mathrm{B}=\mathrm{B}+\mathrm{C}$ was considered, in which $\mathrm{C}$ is the amount in CoCos, we have $\mathrm{V}_{\mathrm{t}}^{\mathrm{b}}=\mathrm{R} \$ 225,788 \mathrm{bn}, \zeta=2.3561$, $\frac{\partial v_{t}^{\mathrm{b}}}{\partial \mathrm{b}}=1.2130, \mathrm{~b}^{*}=\mathrm{R} \$ 5,524 \mathrm{bn}$. To calculate the new amount of subordinated debts $\left(\mathrm{B}_{\mathrm{t}}\right)$, there is Equation 18.

$$
B_{t}=\frac{b}{r}+\left(\theta \lambda \xi_{b}-\frac{b}{r}\right) \mathcal{D}\left(x_{t}, \xi_{b}\right)
$$

Corresponding to the optimal debt coupons $b^{*}, \theta$ will be defined, which is the fraction of the bank's liquidation value that goes to shareholders. For $\theta$, the Bulow and Shoven (1978) example regarding a company going into bankruptcy is used, and the value is calculated by dividing the sum of cash with the present value of future income by the debt securities. Thus, $\theta$ is equal to $4 / 5$ of total bank assets, that is, $0.8 \%$. For $B B, B=$ $\mathrm{R} \$ 45,244 \mathrm{bn}$ and the total debt optimal $\pi=\mathrm{R} \$ 21,760 \mathrm{bn}$, the new threshold $\xi_{\mathrm{b}}=\mathrm{R} \$ 16,471 \mathrm{bn}$, net equity $S_{\mathrm{t}}^{\mathrm{b}}=\mathrm{R} \$ 36,630 \mathrm{bn}$, the value of the bank $V_{t}^{b}=R \$ 229,801 b n$ and the first derivative of $V_{t}^{b}$ with relation to $b^{*} \frac{\partial v_{t}^{b}}{\partial b}=-3.86$.

Once the optimal capital structure with subordinated debts is estimated, it is assumed that the entire subordinated debt coupon $\left(b^{*}\right)$ is transformed into CoCos, that is, $b^{*}=c$, in which $c$ is the coupon of debts in CoCos. The total amount of CoCos is given by Equation 19 .

$$
C_{t}=\frac{c}{r}\left(1-\mathcal{D}\left(x_{t}, x\right)\right)+\gamma \mathcal{D}\left(x_{t}, x\right)\left(\mathcal{V}(x, d)-\mathcal{V}\left(\xi_{c}, d\right) \mathcal{D}\left(x_{t}, \xi_{c}\right)\right)
$$

in which $\gamma$ is the rate of conversion of CoCos. To estimate it, the Pennacchi (2010) and Calormis and Herring (2011) approach is used, which defines it as being the ratio between the amount of optimal debt and of total assets in Equation 20.

$$
\gamma=\frac{\text { optimal B }}{\text { Total Assets }}
$$

The $X$ parameter is the conversion threshold for the CoCos, given by Equation 21 .

$$
\mathcal{X}=\phi(\mathrm{d}+\mathrm{c})
$$

As $^{*}=\mathrm{c}$, then $\mathcal{X}=$ optimal $\pi=\mathrm{R} \$ 21,760 \mathrm{bn}$. And $\xi_{\mathrm{c}}$ is the post-conversion threshold, given by Equation 22 .

$$
\xi_{\mathrm{c}}=\phi(\mathrm{d})
$$

For $\mathrm{BB}, \gamma=0.035, \xi_{\mathrm{c}}=12,289 \mathrm{bn}$ and $\mathrm{C}_{\mathrm{t}}=47,260 \mathrm{bn}$. The net equity and the value of the bank with CoCos are, respectively:

$$
S_{t}^{c}=\mathcal{V}\left(x_{t}, d+c\right)-\mathcal{V}(\mathcal{X}, d+c) \mathcal{D}\left(x_{t}, \mathcal{X}\right)+(1-\gamma) \mathcal{D}\left(x_{t}, \mathcal{X}\right) \mathcal{V}(\mathcal{X}, d)-\mathcal{V}\left(\xi_{c}, d\right) \mathcal{D}\left(x, \xi_{c}\right)
$$

$$
V_{t}^{c}=S_{t}^{c}+C_{t}+D-I_{t}
$$


For $\mathrm{BB}, \mathrm{S}_{\mathrm{t}}^{\mathrm{c}}=36,134 \mathrm{bn}$ and $\mathrm{V}_{\mathrm{t}}^{\mathrm{c}}=231,311 \mathrm{bn}$. Comparing current net equity with the model estimates $\left(S_{t}=R \$\right.$ $\left.45,342 \mathrm{bn}, \mathrm{S}_{\mathrm{t}}^{\mathrm{b}}=\mathrm{R} \$ 36,630 \mathrm{bn}, \mathrm{S}_{\mathrm{t}}^{\mathrm{c}}=\mathrm{R} \$ 36,134 \mathrm{bn}\right)$, it is observed that the proposed increase in the amount of subordinated debts allows a reduction in net equity, given that the greater financing brings greater tax benefits. In the case of CoCos, the reduction in net equity is a little greater, since all or part of this debt is considered as equity by the benefit of the conversion, as well as having a greater tax benefit, given that in general CoCos pay a higher coupon. However, this approach of comparing net equities ignores the fact that the issuance of CoCos alters the bank's total debt capacity; thus, in the same way as happens with subordinated debts, the interest resides in maximizing the company's value through the optimal coupon of $\operatorname{CoCos}\left(c^{\star}\right)$. Koziol and Lawrenz (2012) show that coupon $c^{\star}$ exists, but it is not possible to determine it analytically; thus, the company value maximization equation is given by:

$$
\frac{\partial V_{t}^{c}}{\partial c}=\frac{\tau}{r}-\frac{\zeta^{c}}{r} \mathcal{D}\left(x_{t}, X\right)
$$

in which

$$
\zeta^{c}=\frac{\tau(\pi-c \beta)}{\pi}
$$

For BB, $\frac{\partial \mathrm{v}_{\mathrm{t}}^{\mathrm{c}}}{\partial \mathrm{c}}=5.12$ with $\zeta^{c}=-14.017$. With these results, we proceed to analyze whether CoCos are a good alternative for banks, comparing the maximization of bank value with each one of these debts:

$$
\left.\frac{\partial V_{t}^{b}}{\partial b}\right|_{b=k}<\left.\frac{\partial V_{t}^{c}}{\partial c}\right|_{c=k}
$$

In fact, $\frac{\partial \mathrm{v}_{\mathrm{t}}^{\mathrm{b}}}{\partial \mathrm{b}}=-3.86<\frac{\partial \mathrm{V}_{\mathrm{t}}^{\mathrm{c}}}{\partial \mathrm{c}}=5.12$, and these results provide evidence of two conclusions: given coupon $\mathrm{k}$, in which $\frac{\partial V_{t}^{c}}{\partial c}>0$ for the bank with CoCo, and $\frac{\partial V_{t}^{b}}{\partial b}=0$ for its counterpart with subordinated debts, it is concluded that $c^{*}$ must be greater than $b^{\star}$. Having optimal debt, the value of the bank in CoCos is greater than the value of the bank with subordinated debts, that is, $\mathrm{V}^{\mathrm{b}}\left(\mathrm{b}^{*}\right)<\mathrm{V}^{\mathrm{c}}\left(\mathrm{c}^{*}\right)$. This is because higher coupons allow greater tax bene- fits, without increasing insolvency risk, given the benefit of conversion. At BB: $\mathrm{V}^{\mathrm{b}}\left(\mathrm{b}^{*}\right)=\mathrm{R} \$ 229,802 \mathrm{bn}<\mathrm{V}^{\mathrm{c}}\left(\mathrm{c}^{*}\right)=$ R\$231,312bn.

The bank gets into financial difficulties when cash flow $x_{t}$ touches the threshold $\xi_{b}$, in the case of financing with subordinated debts, and $\xi_{c}$, in the case of CoCos. The likelihood of the bank getting into financial difficulties is given by Equation 28 .

$$
\mathrm{P}_{\xi, \mathcal{T}}=\mathrm{N}\left(\frac{\overline{\mathrm{Z}}-\widehat{\mu} \mathrm{T}}{\sigma \sqrt{\mathrm{T}}}\right)+\exp \left\{\frac{2 \hat{\mu} \overline{\mathrm{z}}}{\sigma^{2}}\right\} \mathrm{N}\left(\frac{\overline{\mathrm{Z}}+\widehat{\mu} \mathrm{T}}{\sigma \sqrt{\mathrm{T}}}\right)
$$

in which $\bar{Z}=\log \left(\frac{\xi}{x_{0}}\right), \hat{\mu}=\mu-\frac{\sigma^{2}}{2}$ and $N($.$) is the standard$ normal cumulative distribution tunction. The model expects that $\mathrm{P}_{\xi_{\mathrm{c}} \mathrm{T}}<\mathrm{P}_{\xi_{\mathrm{b}}, \mathrm{T}}$ and, in fact, for $\mathrm{BB}$, the inequality is verified: $\mathrm{P}_{\xi_{\mathrm{C}} \mathrm{T}}=0.00000010357864 \%<\mathrm{P}_{\xi_{\mathrm{b}}, \mathrm{T}}=0.048315833 \%$.

Proposal 1 says that a security developed in optimal conditions increases a bank's value and attenuates the gra- vity of financial crises, given the low likelihood of financial difficulties and the lower present value of costs of financial difficulties.

With the results obtained, evidence is provided that Proposal 1 is valid for $\mathrm{BB}$, and so it cannot be rejected, given that: $\phi=0.76<1$ and $\frac{\partial \mathrm{V}_{\mathrm{t}}^{\mathrm{b}}}{\partial \mathrm{b}}=-3.86<\frac{\partial \mathrm{V}_{\mathrm{t}}^{\mathrm{c}}}{\partial \mathrm{c}}=5.12$. 


\subsection{Determination of Optimal Capital with Risk Taking Incentive}

From now on it is assumed that there are no restrictive regulations for risk incentives or displacement and, therefore, banks have the option of relaxing their monitoring of risks, thus avoiding monitoring costs and increasing expected income. The increase in risk comes from the displacement of investments towards assets that are riskier and have a higher expected return, thus, the model assumes that the volatility of current cash flow is $\sigma_{1}$ and banks have the irreversible option of increasing their risk to $\sigma_{h}$, while the return on these flows $(\mu)$ remains unaltered in relation to price. To measure the new likelihood of insolvency embedded in the return on these flows $(\mu)$, the (real) physical rate of deviation $\mu^{\mathrm{P}}$ will be needed. According to Decamps et al. (2004), and Koziol and Lawrenz (2012), the increase in risk $\sigma$ is offset by a corresponding increase in the rate of physical deviation $\left(\mu^{\mathrm{P}}\right)$, for a given market risk price $(\psi>0)$, so that the return over cash flow $(\mu)$ remains constant, that is:

$$
\mu=\mu^{P}-\psi \sigma
$$

for $\psi>0$, consistent with the deduction of Bollen (1997), it is considered that:

$$
\Psi=\frac{\mathrm{r}-\mu}{\sigma}
$$

and for $\mathrm{BB} \psi=0.036884$.

The risk preferences are evaluated by the sign of the first derivative of net equity in relation to the risk parameter $(\sigma)$. For banks with subordinated debts, we have Equation 31.

$$
\frac{\partial S_{t}^{b}}{\partial \sigma}=-\mathcal{V}(\xi, \pi) \frac{\partial}{\partial \sigma} \mathcal{D}\left(x_{t}, \xi, \sigma\right)=-\mathcal{V}(\xi, \pi) \mathcal{D}\left(x_{t}, \xi, \sigma\right) \log \left(\frac{x_{t}}{\xi}\right) \frac{\partial \beta(\sigma)}{\partial \sigma}
$$

with $\mathcal{V}(\xi, \pi)=(1-\tau)\left(\frac{\xi}{r-\mu}-\frac{\pi}{r}\right)$, and which can be interpreted as the present value of perpetual income flow, free of risks and taxes, given a level of profit. For a given level of debt, $\mathcal{V}(\xi, \pi)$ is negative when the conversion threshold $\xi$ is sufficiently small, and positive for a higher threshold. That is, with more rigid financial restrictions (higher $\xi$ threshold), and in the case of insolvency, holders of debt give up a higher value of cash flow in relation to debits, making them apprehensive in relation to the risk of financial stress. In the case of a bank with financing in subordinated debts, the risk preferences depend on the exogenous restriction $\xi$. If the restriction is sufficiently weak, so that the $\xi$ threshold is low, shareholders have incentives to increase risk, that is, $\frac{\partial s_{t}^{b}}{\partial \sigma}>0$. If the restriction is rigid, that is, $\xi$ is sufficiently high, then the holders of debts have incentives to avoid risks, $\frac{\partial s_{t}^{b}}{\partial \sigma}<0$. For BB, we have $\frac{\partial s_{t}^{b}}{\partial \sigma}=60,525>0$, that is, according to the model, BB has a low $\xi$ threshold and, therefore, shareholders have incentives to increase risks. In fact, having incentives to increase risks does not mean that the bank will increase them, but rather, this may show that, despite the bank having the opportunity to increase its risk, it prefers to avoid it. The threshold at which risk preferences change is exactly at the point $\frac{\partial s_{t}^{b}}{\partial \sigma}=0$, and the critical threshold is given by Equation 32 .

$$
\hat{\xi}(\pi)=\pi \frac{r-\mu}{r}
$$

in which: if $\xi>\hat{\xi}$, the bank does not have a preference for high risk, and if $\xi<\hat{\xi}$, the bank has incentives for increasing risks, and if $\xi=\hat{\xi}$, the bank is indifferent to the risk level strategy.

The threshold $\hat{\xi}$ suggests two intuitive characteristics, na- mely: first, it depends directly on the bank's potential for growth, that is, for a high $\mu$, the $\hat{\xi}$ will be low and the bank will be able to raise capital in levels of cash flow for which a bank with lower growth would already find itself in financial diffi- 
culties; and second, the threshold depends on the payment of interest $(\pi)$, that is, if the level of debt is high, it is likely for the bank to suffer financial difficulties more quickly. If the bank does not suffer any exogenous restriction, the endogenous threshold, called the optimal threshold, could be given by Equation 33 .

$$
\xi^{*}(\pi)=\pi \frac{r-\mu}{r} \frac{\beta}{\beta-1}
$$

Given that $\frac{\beta}{\beta-1}<1$, the optimal endogenous threshold will always be lower than the critical threshold $\hat{\xi}\left(\xi^{*}<\hat{\xi}\right)$, which shows that, free from financial restrictions, banks will always have the incentive to increase risks. For BB: critical $\hat{\xi}=\mathrm{R} \$ 18,922 \mathrm{bn}, \xi=\mathrm{R} \$ 16,472 \mathrm{bn}$, optimal $\xi^{*}=\mathrm{R} \$$ $15,601 \mathrm{bn}$. With its threshold $\xi$ under the critical threshold $(\xi<\hat{\xi})$, BB would have incentives to increase risks, consistent with the results for the sign for the net equity derivative in relation to risk $\frac{\partial s_{t}^{b}}{\partial \sigma}>0$. It can also be noted that the
critical threshold is above the optimal threshold $\left(\xi^{*}<\hat{\xi}\right)$, as expected.

Assuming now that $\xi(\pi)=\hat{\xi}(\pi)$, we will analyze how risk preferences change when a bank, at the optimal debt level, exchanges subordinated debts for CoCos. Again, the sign for the net equity derivative with relation to risk in Equation 34.

$$
\frac{\partial S_{t}^{c}}{\partial \sigma}=(1-\gamma) \mathcal{V}(X, d) \frac{\partial}{\partial \sigma} \mathcal{D}\left(x_{t}, \chi\right)=(1-\gamma) \mathcal{V}(X, d) \mathcal{D}\left(x_{t}, \chi\right) \log \left(\frac{x_{t}}{x}\right) \frac{\partial \beta(\sigma)}{\partial \sigma}
$$

in which $X=\hat{\xi}(\mathrm{d}+\mathrm{c})$ is the conversion threshold for CoCos, at the moment in which the external restriction is mandatory. After conversion, if profits continue falling, the new threshold for financial difficulties will be $\xi_{c}=\hat{\xi}(d)$. By the definition of $X$ and $\xi_{c}$ the terms $\mathcal{V}(X, d+c)$ and $\mathcal{V}\left(\xi_{c} d\right)$ in Equation 19 are equal to zero. Again, the sign of the derivative is defined by $\mathcal{V}(X, \mathrm{~d})=(1-\tau)\left(\frac{X}{\mathrm{r}-\mu}-\frac{\mathrm{d}}{\mathrm{r}}\right)=(1-\tau)\left(\frac{\mathrm{c}}{\mathrm{r}}\right)>0$, and $\mathcal{V}(X, d)$ will always be positive for $\gamma<1$. Thus, while current shareholders maintain a positive fraction of cash flow rights $(\gamma<1)$, that is, they continue benefiting from conversion, $\frac{\partial S_{t}^{c}}{\partial \sigma}$ will always be positive, and they will always have the incentive to increase risk.

Proposal 2: it is a bank with subordinated debts that begins experiencing financial difficulties $\left(X=\hat{\xi}(\mathrm{d}+\mathrm{c})\right.$ and $\xi_{c}=\hat{\xi}$ (d)), which leads management to be indifferent to an increase in risk $\left(\frac{\partial s_{t}^{b}}{\partial \sigma}=0\right)$. If the bank exchanges subordinated debts for CoCos, in an optimal way, in which current shareholders maintain a positive fraction of cash flow $(\gamma<1)$, managers will always have the incentive to increase risk, $\frac{\partial \mathrm{s}_{\mathrm{C}}^{\mathrm{C}}}{\partial \sigma}>0$.

The numbers for BB are: $\mathcal{X}=\mathrm{R} \$ 18,922 \mathrm{bn}, \gamma=0.3135$, $\frac{\partial \mathrm{s}_{\mathrm{t}}^{\mathrm{c}}}{\partial \sigma}=$ 139.003, confirming Proposal 2.

The incentive to increase risk by return is also present when risk restrictions exist, but are weak and allow arbitration, like for example, in the case of a regulation that does not define the CoCo conversion threshold. Thus, when a bank exchanges its subordinated debts for CoCos, maintaining the coupon $(\mathrm{b}=\mathrm{c})$, the CoCos increase managers' incentive for risk so that $\frac{\partial s_{t}^{b}}{\partial \sigma}<\frac{\partial S_{t}^{c}}{\partial \sigma}$.

Proposal 3: with weak financial restrictions, banks will prefer to take more risk to maintaining capital at an optimal level, in both debts. In the case of strong financial restrictions, banks will always prefer low risk with subordinated debts, even if they can opt for higher risk with financing in
CoCos at the optimal level. That is, for $\xi=\phi \pi$, the optimal level of debt follows the rule: if $\xi<\hat{\xi}$, then $0<\left.\frac{\partial S_{t}^{b}}{\partial \sigma}\right|_{b=b^{*}}<\left.\frac{\partial S_{t}^{c}}{\partial \sigma}\right|_{c=c^{*}}$ in which banks prefer to take more risk to maintaining capital at the optimal level, in both debts; and if $\xi>\hat{\xi}$, then $\left.\frac{\partial s_{t}^{b}}{\partial \tau}\right|_{b=b^{*}}<0$ and $\left.\frac{\partial s_{t}^{C}}{\partial \sigma}\right|_{c=c^{\ddagger}} \leqslant 0$, in which banks prefer low risk with subordinated debts, even though they can opt for higher risk with CoCos at the optimal level.

For BB: $\frac{\partial s_{t}^{b}}{\partial \sigma}=60,525<\frac{\partial S_{t}^{c}}{\partial \sigma}=139,003, \xi=16,472<$ critical $\hat{\xi}$ $=18,922$ and $\frac{\partial s_{t}^{b}}{\partial \sigma}=60,525 \stackrel{\partial \sigma}{<} \frac{\partial \mathcal{S}_{t}^{c}}{\partial \sigma}=139,003$. From the model, BB will never prefer high risk with financing in subordinated debts, but prefers low risk with financing in CoCos.

The proposals of Koziol and Lawrence (2012) show that CoCos, in an environment with regulatory restrictions that allow arbitrage, increase the incentive for risk, which may lead to financial crises. This is because shareholders holding CoCos, in the case of financial difficulties, convert the debts maintaining their equity value, independently of whether such difficulties were caused by external motives like an economic crisis or by managers' recklessness in the sense of taking on more risk to obtain higher returns. This does not occur in the case of subordinated debts, in which financial difficulty leads to insolvency and, in this case, shareholders are the last to receive their obligations, if they do receive them. Thus, in non regulated environments or those with weak restrictions, subordinated debts work as an internal regulation, or a disciplinary device. If subordinated debts are substituted by CoCos this device is mitigated and the incentives for risk can be distorted. Analyzing the impacts of displacement of risk on the banks' net value, in an environment with complete information, investors can rationally anticipate shareholders' risk choices and charge the corresponding price for this, that is, the debts will be priced according to the expected value of their risk $\sigma$. Thus, subordinated debts 
would be priced assuming a lower risk $\left(\sigma_{l}\right)$, while CoCos would be priced assuming a higher risk $\left(\sigma_{h}\right)$. Consequently, the value of banks with CoCos tends to be lower than the value of banks that have only subordinated debts; this is because, in general, in trade-off models, the tax benefits of debts are worth it while the bank is solvent, but incur heavy losses in the case of insolvency. A higher risk increases the likelihood of insolvency, which increases the present value of losses, without any additional advantage. Thus, the value of bank $V_{t}^{b}$ negatively depends on its risk $\sigma$, that is,

$$
\frac{\partial V_{t}^{b}}{\partial \beta}=-\pi \frac{\tau}{r}\left(\frac{x}{\xi_{b}}\right)^{\beta} \log \left(\frac{x}{\xi_{b}}\right)<0
$$

for subordinated debts and

$$
\frac{\partial V_{t}^{c}}{\partial \beta}=\frac{d \tau(\mu-r)+\xi_{c} r(\lambda-(1-\tau))}{r(r-\mu)}\left(\frac{x}{\xi_{c}}\right)^{\beta} \log \left(\frac{x}{\xi_{c}}\right)-\frac{c \tau}{r}\left(\frac{x}{x}\right)^{\beta} \log \left(\frac{x}{x}\right)<0
$$

for CoCos. It was previously defined that $V^{b}\left(b^{\star}\right)<V^{c}\left(c^{\star}\right)$, that is, the value of banks with CoCos is greater than the value with subordinated debts. In fact, this relationship will only be inverted in the case of a very large change in the risk preferences of a bank, that is, with an very large increase in volatility $\left(\sigma_{h}\right)$, reaching the critical level defined by $\hat{\sigma}=\sup \left\{\sigma_{h} \mid V_{t}^{c}\left(\sigma_{h}\right) \geq V_{t}^{b}\left(\sigma_{p}\right)\right\}$, if not, the relationship is maintained. To analyze Brazilian banks, it is defined that the high risk $\left(\sigma_{h}\right)$ be considered the critical level $(\hat{\sigma})$, that is, $\sigma_{h}=\hat{\sigma}$. For BB: $V_{t}^{c}\left(\sigma_{h}\right) \geq V_{t}^{b}\left(\sigma_{p}\right)$, that is, $\frac{\partial V_{t}^{b}}{\partial \beta}=-6,510$ and $\frac{\partial V_{t}^{c}}{\partial \beta}=$ $-5,000<0$ and $\sigma_{l}=0.11196323$ or $11 \%, \sigma_{h}=\hat{\sigma}=0.1228368$ or $12.28 \%$. According to the model, the value of BB negatively depends on the risk $(\sigma)$, that is, an increase in the risk $\sigma$ leads to a fall in the value of the bank $V(\sigma)$. Two points are worth highlighting: despite the greater risk associated, even still we expect to observe a higher value for the bank with
CoCos than with subordinated debts, because the relaxing of financial restrictions leads the bank to take on more loans and, consequently, to have higher tax benefits, that is, to pay fewer taxes. Moreover, the spread required by investors for CoCos is higher than for subordinated debts, since they are constructed to be converted at the moment in which banks' shares have the lowest value, that is, the high spread works as an insurance premium. Thus, banks with CoCos issued with a lower risk than the critical value $\left(\sigma_{h}<\hat{\sigma}\right)$ have a higher global value and imply greater wealth for shareholders.

Evaluating CoCos from a systemic point of view, the likelihood of insolvency will be considered, observing the differences in the risk parameters $\left(\sigma_{h}, \sigma_{l}\right)$, extending the notation of the probability of insolvency to $P_{\xi, \sigma T}$ and calculating their difference in a time horizon $\mathrm{T}$ :

$$
\Delta P_{T}=P_{\xi, \sigma_{h}, T}-P_{\xi, \sigma_{l}, T}
$$

From Proposal 1, for $\sigma_{h}=\sigma_{l}, \Delta P_{T}$ is negative and grows uniformly with $\sigma_{h}$, that is, another critical value for $\bar{\sigma}$ exists in which the difference $\Delta P_{T}$ becomes positive, $(\bar{\sigma})$ $=\inf \left\{\sigma_{h} \mid P_{\xi, \sigma_{h}, T} \geq P_{\xi, \sigma_{l} T}\right\}$. This reinforces the initial proposal that CoCos have benefits in situations of financial difficulties, while banks do not have the ability to choose the risk that they will assume, that is, until $\sigma_{h}=\sigma_{l}$. However, in non regulated environments or those with weak regulation, the likelihood of financial difficulties increases by the same proportion as the risk taken, and ends up offsetting the initial beneficial effects, with the critical limit for growth of risk the $\bar{\sigma}$, above which banks, in fact, begin suffering financial difficulties, that is, there are levels of risk $\sigma_{h}$ for which CoCos are an optimal ex ante strategy, increasing the values of banks, but with a greater likelihood of default in relation to subordinated debts. For BB: $\sigma_{l}=0.11196323$, $\sigma_{h}=0.12068323, \bar{\sigma}=0.12283679$. This means that risk $\sigma_{l}=$ 0.11196323 may increase to $\sigma_{h}=0.12068323$ even without financial difficulties, but with a greater likelihood of insolvency. However, the limit for risk taking is $\sigma=0.12283679$, in which the bank would begin to have financial difficulties, that is, according to the model and without restriction on increasing risks, $\mathrm{BB}$ would have the incentive to take more risks with CoCos; and there is a limit of risk $\bar{\sigma}$ from which the bank would begin suffering financial difficulties. With these results, Hypothesis 2 cannot be rejected, given that $\frac{\partial s_{t}^{b}}{\partial \sigma}=60,525<\frac{\partial S_{t}^{c}}{\partial \sigma}=139,003$. According to this model and with the adopted assumptions, the 10 biggest Brazilian 
banks in terms of total assets will be analyzed.

\subsection{Sample Analysis}

The sample is composed of the 10 biggest commercial banks in terms of total assets belonging to the SFN, with the analysis covering 1Q2009 to 4Q2013 (5 years). The SFN is very diverse and with a large concentration of assets and net equity (NE) in these 10 banks, and so the SFN was divided into three NE bands, in order to group banks of the same size:

a) Below $1 \%$ : NE of up to $1 \%$ of the SFN (86 banks - 15\% of the SFN);

b) Between $1 \%$ and 3\%: NE from $1 \%$ to $3 \%$ of the SFN (5 banks $-11 \%$ of the SFN);

c) Above 3\%: NE of 3\% or more of the SFN (5 banks $74 \%$ of the SFN).

The study sample is concentrated in groups b and c, and the model's main variables are: threshold $(\xi)$, regulatory restriction $(\phi)$, NE and the amount of subordinated debts. To separate them from the SFN total, the percentages of each band's participation out of the total for the variable are ap- plied. Thus, for the regulatory threshold, the percentages $74 \%$, $15 \%$, and $11 \%$, are applied to the SFN's total RWA, divided by total banks in the band and, to these values, the percentage $4.5 \%$ is applied (minimum regulatory capital required, before conversion). For the NE statistic, only the percentages of total $\mathrm{NE}$ is applied and divided by total banks in the band, in order to obtain the average per bank. For the statistic for subordinated debts and equity and debt hybrid instruments (EDHI), we use the columns with the balance of accounts 49996003, 49997002, 49995004, and 49998001 from the Plano Contábil, or Chart of Accounts, (COSIF: Available from http://www. bcb.gov.br/?COSIF) of each database, summing the Others column. These COSIF accounts have a balance of subordinated debts and EDHI. Table 3 presents the variables used by the model, and Table 4, the results for the banks in the sample.

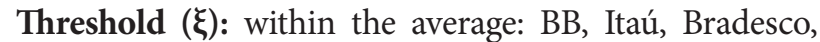
BTG Pactual (BTG), HSBC, and Safra. Outliers: CEF, Santander, Votorantim, and Citibank, with a lower threshold than the mean for the SFN.

\section{Table 3}

Descriptive statistic

\begin{tabular}{|c|c|c|c|c|}
\hline Variable & Indicator & below $1 \%$ & between $1 \%$ and $3 \%$ & above $3 \%$ \\
\hline & Mean & 236 & 2,553 & 16,838 \\
\hline \multirow[t]{3}{*}{ Threshold } & Median & 215 & 2,327 & 15,348 \\
\hline & Standard Deviation & 62 & 669 & 4,415 \\
\hline & Mean & 710 & 7,667 & 50,574 \\
\hline \multirow[t]{3}{*}{ Net Equity } & Median & 712 & 7,687 & 50,706 \\
\hline & Standard Deviation & 133 & 1,441 & 9,502 \\
\hline & Mean & 719 & 7,763 & 51,203 \\
\hline \multirow[t]{3}{*}{ Subordinated Debts and EDHI } & Median & 644 & 6,961 & 45,912 \\
\hline & Standard Deviation & 250 & 2,705 & 17,845 \\
\hline & Mean & 0.63 & 0.63 & 0.63 \\
\hline$\Phi$ & Median & 0.62 & 0.62 & 0.62 \\
\hline
\end{tabular}

Source: Financial Stability Report and BACEN Top 50. Developed by the authors.

Table 4 Descriptive statistic of the 10 biggest banks in Brazil

\begin{tabular}{|c|c|c|c|c|c|c|c|c|c|c|c|c|c|}
\hline Variable & Indicator & $\begin{array}{c}\text { between } \\
1 \% \mathrm{e} \\
3 \%\end{array}$ & $\begin{array}{l}\text { BTG } \\
\text { Pactual }\end{array}$ & HSBC & Safra & Votorantim & Citibank & $\begin{array}{l}\text { above } \\
3 \%\end{array}$ & $\begin{array}{l}\text { Banco } \\
\text { do } \\
\text { Brasil }\end{array}$ & $\begin{array}{l}\text { Itaú Uni- } \\
\text { banco }\end{array}$ & $\begin{array}{l}\text { Caixa } \\
\text { Econô- } \\
\text { mica } \\
\text { Federal }\end{array}$ & Bradesco & Santander \\
\hline \multirow{3}{*}{ Threshold } & Mean & 2,553 & & & & & & 16,838 & & & & & \\
\hline & Median & 2,327 & 1,525 & 2,165 & 1,547 & 890 & 303 & 15,348 & 16,472 & 14,505 & 8,475 & 14,538 & 4,265 \\
\hline & $\begin{array}{l}\text { Standard } \\
\text { Deviation }\end{array}$ & 669 & & & & & & 4,415 & & & & & \\
\hline \multirow{3}{*}{$\begin{array}{l}\text { Net } \\
\text { Equity }\end{array}$} & Mean & 7,667 & & & & & & 50,574 & & & & & \\
\hline & Median & 7,687 & 10,317 & 3,386 & 7,577 & 6,004 & 747 & 50,706 & 45,343 & 59,349 & 74,604 & 76,592 & 29,390 \\
\hline & $\begin{array}{l}\text { Standard } \\
\text { Deviation }\end{array}$ & 1,441 & & & & & & 9,502 & & & & & \\
\hline \multirow{3}{*}{$\begin{array}{l}\text { Subor- } \\
\text { dinate } \\
\text { Debts and } \\
\text { EDHI }\end{array}$} & Mean & 7,763 & & & & & & 51,203 & & & & & \\
\hline & Median & 6,961 & 15,755 & 7,450 & 8,792 & 1,977 & 711 & 45,912 & 45,245 & 141,532 & 72,776 & 132,677 & 42,171 \\
\hline & $\begin{array}{l}\text { Standard } \\
\text { Deviation }\end{array}$ & 2,705 & & & & & & 17,845 & & & & & \\
\hline \multirow{3}{*}{$\Phi$} & Mean & 0.63 & & & & & & 0.63 & & & & & \\
\hline & Median & 0.62 & 0.61 & 0.86 & 0.78 & 0.77 & 0.76 & 0.62 & 0.76 & 0.66 & 0.73 & 0.66 & 0.57 \\
\hline & $\begin{array}{l}\text { Standard } \\
\text { Deviation }\end{array}$ & 0.03 & & & & & & 0.03 & & & & & \\
\hline
\end{tabular}

Source: Financial Stability Report (Mar/10 to Mar/14) and BACEN Top 50 Report and banks' balance sheets. Developed by the authors. 
Regulatory restriction $(\phi)$ : Itaú, Bradesco, and BTG. Outliers: BB, CEF, Safra, HSBC, Votorantim, and Citibank, with regulatory restriction above the average, suggesting RE closer to RRE. Santander exhibited a lower regulatory restriction than the average, suggesting $\mathrm{RE}$ further from RRE.
Subordinated Debts and EDHI: within the average: BB, Santander, HSBC, and Safra. Outliers: Itaú, CEF, Bradesco, and BTG, with subordinated debts above the average, suggesting more financing than required by BACEN; Votorantim and Citibank, with subordinated debts below their band, suggesting more own equity than in financing.

\section{RESULTS ANALYSIS}

The 10 biggest banks in terms of total assets in the SFN are, in descending order: BB, Itaú, Caixa Econômica Federal (CEF), Bradesco, Santander, HSBC, Safra, BTG, Votorantim, and Citibank (BACEN TOP 50 - Dec/13), totaling approximately $\mathrm{R} \$ 5 \mathrm{tn}, 75.1 \%$ of the SFN. The Koziol and Lawrenz (2012) model estimates optimal debt, based on NE estimated by cash flow. However, in Brazil, banks' NE is not composed solely of share capital and profits, with there being other elements that generate displacement between real and estimated NE. However, our interest here is in evaluating the capital structure comparatively and, for the same bank, with subordinated debts and CoCos; thus, an increase or reduction in NE does not alter the bank's internal relationship with CoCos or subordinated debts.

If $\mathrm{b}^{*}$ is the optimal debt coupon estimated by the model, and current $b$ is the current coupon, then except for Votorantim, all of the banks would increase their debt coupons, as in Table 5 .

Table 5 Debt coupon and net equity of banks

\begin{tabular}{|c|c|c|c|c|c|c|c|c|c|c|}
\hline Parameter & $\begin{array}{c}\text { Banco do } \\
\text { Brasil }\end{array}$ & Itaú Unibanco & $\begin{array}{c}\text { Caixa Econômica } \\
\text { Federal }\end{array}$ & Bradesco & Santander & $\begin{array}{c}\text { BTG } \\
\text { Pactual }\end{array}$ & HSBC & Safra & Votorantim & Citibank \\
\hline $\mathbf{b}^{*}$ & 5,525 & 14,855 & 7,569 & 13,806 & 4,459 & 2,127 & 775 & 914 & 218 & 74 \\
\hline current b & 3,838 & 3,809 & 2,348 & 1,072 & 682 & 731 & 293 & 37 & 646 & 0 \\
\hline $\mathrm{S}_{\mathrm{t}}^{\mathrm{b}}$ & 45,343 & 59,349 & 74,604 & 76,592 & 29,390 & 10,317 & 3,386 & 7,577 & 6,004 & 747 \\
\hline Current NE & 72,225 & 81,024 & 35,373 & 70,940 & 62,819 & 16,091 & 10,009 & 7,559 & 7,141 & 6,851 \\
\hline
\end{tabular}

Source: Developed by the authors.

The results expected for hypothesis 1 are described in Table 6, and the results for each bank compose Table 7 .

Table 6 Results expected by the model to analyze hypothesis 1

\begin{tabular}{|c|c|c|c|}
\hline Parameter & Description & Expected Result & Justification \\
\hline$\Phi$ & $\begin{array}{l}\text { Regulatory restriction on mini- } \\
\text { mum capital }\end{array}$ & $\Phi<1$ & $\begin{array}{l}\text { Bank is able to raise new capital to avoid insol- } \\
\text { vency, even with cash flow lower than the total } \\
\text { to be paid in interest. }\end{array}$ \\
\hline$V_{t}^{b}, V_{t}^{c}$ & Value of bank & $V_{t}^{b}<V_{t}^{c}$ & $\begin{array}{l}\text { Value of bank, with contingent convertibles, is } \\
\text { greater than the value with subordinated debts, } \\
\text { since the benefit of conversion requires higher } \\
\text { coupons, and higher tax benefits. }\end{array}$ \\
\hline$\frac{\partial V_{t}^{b}}{\partial b}, \frac{\partial V_{t}^{c}}{\partial c}$ & Maximization of value of bank & $\frac{\partial V_{t}^{b}}{\partial b}<\frac{\partial V_{t}^{c}}{\partial c}$ & $\begin{array}{l}\text { Shows that the optimal coupon in subordinated } \\
\text { debts }\left(b^{*}\right) \text { must be lower than the optimal cou- } \\
\text { pon in contingent convertibles. }\end{array}$ \\
\hline $\mathrm{P}_{\xi_{\mathrm{c}}, \mathrm{T}^{\prime}} \mathrm{P}_{\xi_{\mathrm{b}}, \mathrm{T}}$ & Probability of insolvency & $P_{\xi_{c}, T}<P_{\xi_{b}, T}$ & $\begin{array}{l}\text { The probability of insolvency of contingent con- } \\
\text { vertibles is lower than the probability of subordi- } \\
\text { nated debts, given the benefit of conversion. }\end{array}$ \\
\hline
\end{tabular}

Source: Developed by the authors.

Value of Bank $\left(V_{t}^{b} e V_{t}^{c}\right)$ : with optimal debt, the evidence shows a higher value for banks financed by $\mathrm{Co}$ Cos than for those with subordinated debts, with the exception of CEF, Safra, and Citibank, which exhibit equal values, suggesting that the proposed structure is indifferent to the type of financing. No bank exhibited a lower value, with CoCos, than the value with subordinated debts.

Maximization of value of bank $\left(\frac{\partial v_{t}^{b}}{\partial b}<\frac{\partial v_{t}^{c}}{\partial c}\right)$ : all the banks exhibited a higher CoCo coupon than that for subordinated debts, that is, the value of a bank with CoCos would be higher than the value with subordinated debts. 
Table 7 Results for the banks for hypothesis 1

\begin{tabular}{|c|c|c|c|c|c|c|c|c|c|c|}
\hline Parameter & $\begin{array}{c}\text { Banco do } \\
\text { Brasil }\end{array}$ & Itaú Unibanco & $\begin{array}{c}\text { Caixa Econômica } \\
\text { Federal }\end{array}$ & Bradesco & Santander & $\begin{array}{c}\text { BTG } \\
\text { Pactual }\end{array}$ & HSBC & Safra & Votorantim & Citibank \\
\hline$\Phi$ & 0.76 & 0.66 & 0.73 & 0.66 & 0.57 & 0.61 & 0.86 & 0.78 & 0.77 & 0.76 \\
\hline $\mathbf{b}^{*}$ & 5,525 & 14,855 & 7,569 & 13,806 & 4,459 & 2,127 & 775 & 914 & 218 & 74 \\
\hline$S_{t}^{b}$ & 36,630 & 7,835 & 86,375 & 30,061 & 31,732 & 532 & 3,221 & 7,148 & 15,820 & 2,198 \\
\hline$S_{t}^{c}$ & 36,124 & 8,306 & 86,375 & 30,088 & 31,988 & 2,185 & 3,224 & 7,148 & 16,397 & 2,183 \\
\hline $\mathrm{V}_{\mathrm{t}}^{\mathrm{b}}\left(\mathrm{b}^{*}\right)$ & 229,802 & 217,007 & 198,490 & 241,793 & 102,705 & 20,003 & 27,478 & 26,225 & 26,803 & 6,003 \\
\hline $\mathrm{V}_{\mathrm{t}}^{\mathrm{c}}\left(\mathrm{c}^{*}\right)$ & 231,312 & 217,560 & 198,490 & 241,828 & 102,980 & 22,264 & 27,481 & 26,225 & 26,923 & 6,003 \\
\hline$\frac{\partial V_{t}^{b}}{\partial b}$ & -3.85 & 3.16 & 3.85 & 3.80 & 3.50 & -3.85 & 3.73 & 3.85 & 3.10 & 3.84 \\
\hline$\frac{\partial V_{t}^{c}}{\partial c}$ & 5.12 & 3.85 & 3.85 & 3.87 & 3.99 & 5.12 & 3.92 & 3.85 & 4.36 & 3.85 \\
\hline$P_{\xi_{b}, T}$ & $0.05 \%$ & $0.00 \%$ & $0.00 \%$ & $0.00 \%$ & $0.00 \%$ & $2.89 \%$ & $0.00 \%$ & $0.00 \%$ & $0.00 \%$ & $0.00 \%$ \\
\hline
\end{tabular}

Source: Developed by the authors.

Probability of insolvency $\left(P_{\xi_{c}, T} P_{\xi_{b}, T}\right)$ : the probabilities are very close to zero for both debts - with the exception of $\mathrm{BB}$, with a likelihood of insolvency of $0.48 \%$, and of BTG Pactual, with 2.28\%, both with subordinated debts. No bank exhibited a greater likelihood of insolvency with CoCos than with subordinated debts.

Thus, through the Koziol and Lawrenz (2012) model and with the assumptions used, we have evidence that the results for all of the banks are compatible with hypothesis 1 .

For hypothesis 2, Table 8 shows the expected results, and Table 9 exhibits those found.

Derivatives of net equity over risk $\left(\frac{\partial s_{t}^{b}}{\partial \sigma}, \frac{\partial S_{t}^{c}}{\partial \sigma}\right)$ : the result with subordinated debts was positive for BB, Itaú Unibanco, Bradesco, Santander, BTG Pactual, HSBC, and Citibank. From the model, these banks should have a low threshold with the incentive to take more risks. For CEF, Safra, and Votorantim, the result was negative, suggesting that these banks have a sufficiently high threshold with the incentive to avoid risks. The result with CoCos was positive for all of the banks, suggesting that they have a sufficiently high threshold and have incentives to avoid risks. The derivative of net equity over risk for all of the banks was higher with CoCos than with subordin: $\frac{\partial S_{t}^{b}}{\partial \sigma} \mathrm{l} d \frac{\partial S_{t}^{c}}{\partial \sigma} s<$ , suggesting that CoCos increase the incentive tor risk when no risk restrictions exist.

Table 8 Results expected by the model for analyzing hypothesis 2

\begin{tabular}{|c|c|c|c|}
\hline Parameter & Description & Expected Results & Justification \\
\hline$\Phi$ & $\begin{array}{l}\text { Regulatory restriction for } \\
\text { minimum capital }\end{array}$ & $\Phi<1$ & $\begin{array}{l}\text { Bank is able to raise new capital to avoid insolvency, } \\
\text { even with cash flow lower than the total to be paid } \\
\text { in interest. }\end{array}$ \\
\hline$V_{t}^{b}, V_{t}^{c}$ & Value of bank & $V_{t}^{b}<V_{t}^{c}$ & $\begin{array}{l}\text { Value of bank, with contingent convertibles, is grea- } \\
\text { ter than the value with subordinated debts, since the } \\
\text { benefit of conversion requires higher coupons, and } \\
\text { greater tax benefits. }\end{array}$ \\
\hline$\frac{\partial V_{t}^{b}}{\partial b}, \frac{\partial V_{t}^{c}}{\partial c}$ & Maximization of value of bank & $\frac{\partial V_{t}^{b}}{\partial b}<\frac{\partial V_{t}^{c}}{\partial c}$ & $\begin{array}{l}\text { Shows that the optimal coupon in subordinated } \\
\text { debts }\left(b^{*}\right) \text { must be lower than the optimal coupon in } \\
\text { contingent convertibles. }\end{array}$ \\
\hline $\boldsymbol{P}_{\xi c, T^{\prime}} \boldsymbol{P}_{\xi b, T}$ & Probabilities of insolvency & $P_{\xi c, T}<P_{\xi b, T}$ & $\begin{array}{c}\text { The probability of insolvency of contingent conver- } \\
\text { tibles is lower than the probability of subordinated } \\
\text { debts, given the benefit of conversion. }\end{array}$ \\
\hline$\frac{\partial s_{t}^{b}}{\partial \sigma}$ & $\begin{array}{l}\text { Derivative of net equity over } \\
\text { risk with subordinated debts }\end{array}$ & $\frac{\partial s_{t}^{b}}{\partial \sigma}<0$ & $\begin{array}{l}\text { Sufficiently high } \xi \text { threshold and shareholders have } \\
\text { the incentive to avoid risks. }\end{array}$ \\
\hline \multirow[b]{3}{*}{$\xi$} & \multirow[b]{3}{*}{ Conversion threshold } & $\xi>$ critical $\xi$ & Bank does not have a preference for high risk. \\
\hline & & $\xi<$ critical $\xi$ & Bank has incentives to increase risks. \\
\hline & & $\xi=$ critical $\xi$ & Bank is indifferent to the risk strategy. \\
\hline
\end{tabular}


Table 8 Continued

\begin{tabular}{|c|c|c|c|c|}
\hline & \multirow{2}{*}{$\frac{\partial \mathrm{S}_{\mathrm{t}}^{\mathrm{c}}}{\partial \sigma}$} & \multirow{2}{*}{$\begin{array}{l}\text { Derivative of net equity over } \\
\text { risk with convertible contin- } \\
\text { gents }\end{array}$} & $>C \frac{\partial \mathrm{S}_{\mathrm{t}}^{\mathrm{c}}}{\partial \sigma}$ & $\begin{array}{l}\text { Low } \xi \text { threshold and shareholders have the incentive } \\
\text { to take more risk. }\end{array}$ \\
\hline & & & $<\mathrm{C} \frac{\partial \mathrm{S}_{\mathrm{t}}^{\mathrm{C}}}{\partial \sigma}$ & $\begin{array}{l}\text { Sufficiently high } \xi \text { threshold and shareholders have } \\
\text { the incentive to avoid risks. }\end{array}$ \\
\hline , & $\frac{\partial S_{t}^{b}}{\partial \sigma} \quad \frac{\partial \mathrm{S}_{\mathrm{t}}^{c}}{\partial \sigma}$ & $\begin{array}{l}\text { Derivative of net equity over } \\
\text { risk }\end{array}$ & $<\frac{\partial S_{t}^{b}}{\partial \sigma} \quad \frac{\partial S_{t}^{c}}{\partial \sigma}$ & $\begin{array}{l}\text { Contingent convertibles increase the incentive for } \\
\text { risk displacement. }\end{array}$ \\
\hline \multirow[b]{2}{*}{$\xi$} & \multirow[b]{2}{*}{$\frac{\partial S_{t}^{b}}{\partial \sigma} \frac{\partial S_{t}^{c}}{\partial \sigma}$} & \multirow{2}{*}{$\begin{array}{l}\text { Rule for optimal } \\
\text { financing choice }\end{array}$} & $\begin{array}{c}\text { If } \xi<\xi \text { then } \hat{O}< \\
<\left.\right|_{c=c} \frac{\partial S_{t}^{c}}{\partial \sigma}\end{array}$ & $\begin{array}{l}\text { With weak financial restrictions, banks will always } \\
\text { prefer to take more risk than maintain capital at opti- } \\
\text { mal level, whether with subordinated debts, or with } \\
\text { contingent convertibles. }\end{array}$ \\
\hline & & & $\begin{array}{c}\text { If } \xi>\xi \text { then } \\
\text { and }<\left.\right|_{b=b} \frac{\partial s_{t}^{b}}{\partial \sigma} \\
\left.\right|_{c=c^{c}} \frac{\partial S_{t}^{c}}{\partial \sigma} \quad \lessgtr\end{array}$ & $\begin{array}{l}\text { With strong financial restrictions, banks will always } \\
\text { prefer low risk with subordinated debts, even if they } \\
\text { can opt for higher risk with financing in contingent } \\
\text { convertibles at the optimal level. }\end{array}$ \\
\hline$\sigma$ & & Risk & $\sigma_{I} \leq \sigma_{h} \leq \sigma$ & $\begin{array}{l}\text { A bank's current risk should be lower than the risk at } \\
\text { which the value of the bank with subordinated debts } \\
\text { is equal to the value with contingent convertibles. } \\
\text { And both should be lower than the risk where the } \\
\text { probability of insolvency of the bank with subordina- } \\
\text { ted debts equals the probability of insolvency of the } \\
\text { banks with contingent convertibles. }\end{array}$ \\
\hline$\Delta \mathrm{P}_{\mathrm{T}}$ & & $\begin{array}{l}\text { Difference between the proba- } \\
\text { bilities of insolvency }\end{array}$ & $\Delta \mathrm{P}_{\mathrm{Tb}-\mathrm{c}} \leq 0$ & $\begin{array}{l}\text { The probability of insolvency of contingent conver- } \\
\text { tibles is higher than that of subordinated debts in a } \\
\text { non regulated environment. However, the delta is } \\
\text { expected to be negative. }\end{array}$ \\
\hline
\end{tabular}

Source: Developed by the authors.

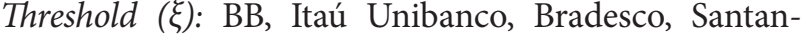
der, BTG Pactual, HSBC, and Citibank exhibited a lower threshold than the critical threshold $(\xi<$ critical $\hat{\xi})$, suggesting that they have incentives for taking risks. CEF, Safra, and Votorantim exhibited a higher threshold than the critical threshold $(\xi>$ critical $\hat{\xi}$ ), suggesting that they do not have preferences for high risks. Analyzing the rule for optimal financing choice in the model, BB, Itaú Unibanco, Bra- desco, Santander, BTG Pactual, HSBC, and Citibank follow the rule: if $\xi<\hat{\xi}$ then $0<\left.\frac{\partial s_{t}^{b}}{\partial \sigma}\right|_{b=b^{*}}<\left.\frac{\partial S_{t}^{c}}{\partial \sigma}\right|_{c=c^{*}}$ and they will always prefer taking risk to maintaining capital at an optimal level, whether with subordinated debts or with CoCos. CEF, Safra, and Votorantim follow the rule: if $\xi>\hat{\xi}$ then $\left.\frac{\partial s_{t}^{b}}{\partial \sigma}\right|_{b=b^{*}}<0$ and $\left.\frac{\partial S_{t}^{c}}{\partial \sigma}\right|_{c=c^{*}} \leqslant 0$ and they will always prefer low risk with subordinated debts, even if they can opt for greater risk, with financing in CoCos at the optimal level.

Table 9 Results for the sample banks for hypothesis 2

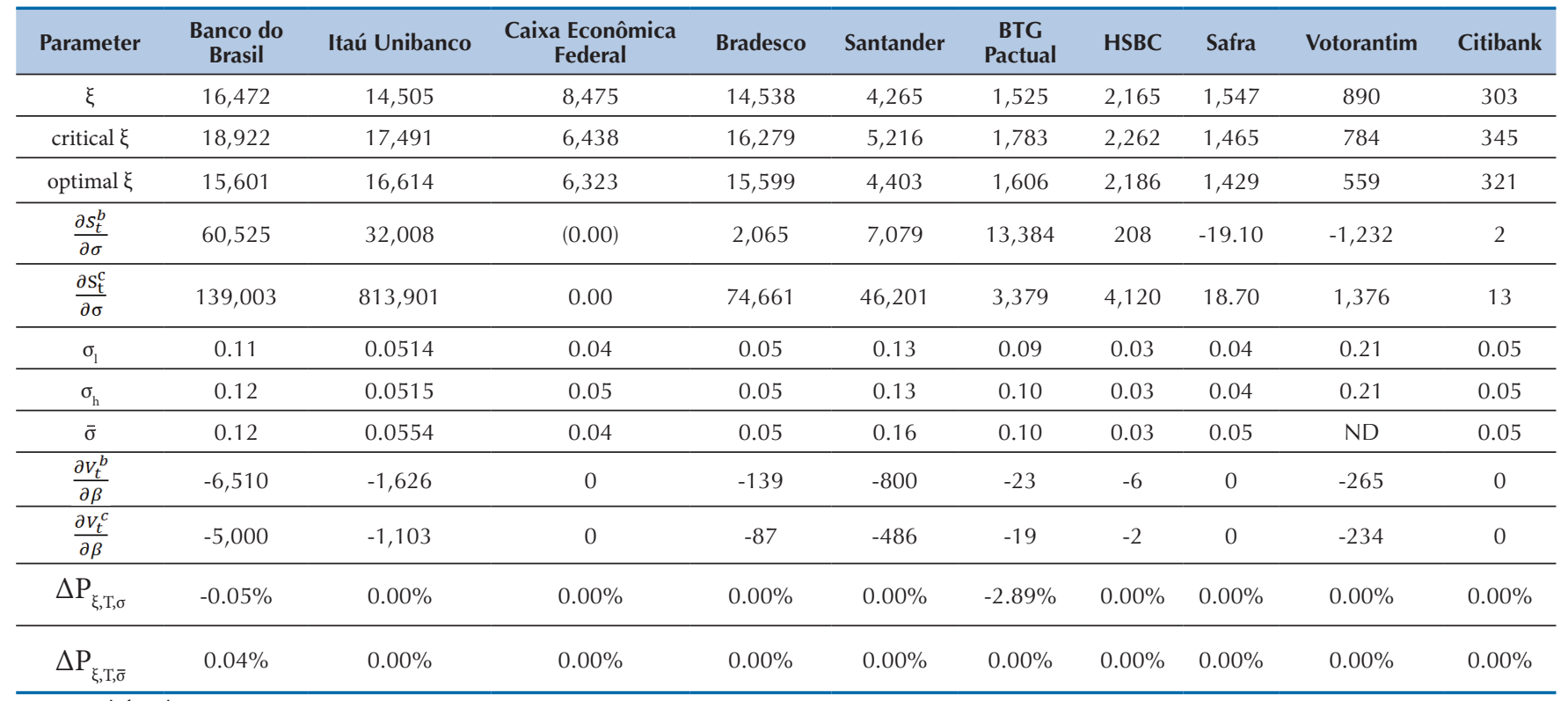


Value of bank with risk $\left(\frac{\partial v_{t}^{b}}{\partial \beta}, \frac{\partial v_{t}^{c}}{\partial \beta}\right)$ : it will be analyzed whether coupons in CoCos are greater than coupons in subordinated debts, through the value of banks. For all of the banks, the derivatives for the value of banks in relation to $\beta$ is negative, suggesting that, even in environments with risks, the optimal coupon in CoCos is greater than the optimal coupon in subordinated debts.

Risk $(\sigma)$ : the risk has 3 different parameters, namely: $\sigma_{l}$ is the risk of the bank with subordinated debts, that is, it should be the lowest risk, even in non regulated environments; $\sigma_{h}$ is the risk of the bank when the value of the bank with subordinated debts equals the value of the bank with $\operatorname{CoCos}\left(\sigma_{h}=\hat{\sigma}=\sup \left\{\sigma_{h} \mid V_{t}^{c}\left(\sigma_{h}\right) \geq V_{t}^{b}\left(\sigma_{\nu}\right)\right\}\right)$. At this moment, the bank is assuming more risk with greater probability of insolvency, however, does not yet suffer from financial difficulties; and lastly, $\bar{\sigma}$ (called critical value) is the limit of risk that the bank can reach before starting to suffer from financial difficulties, that is, it is the level at which the probabilities of insolvency with subordinated debts and CoCos is equal $\left(\bar{\sigma}=\inf \left\{\sigma_{h} \mid P_{\xi, \sigma_{h}, T} \geq P_{\xi, \sigma_{h} T}\right\}\right)$. The results for the capital structure proposed by the model are:

$\sigma_{l}<\sigma_{h}<\overline{\boldsymbol{\sigma}}-\mathrm{BB}$, Itaú Unibanco, and Santander: low risk in non regulated environments, and where this risk may increase in search of higher returns, up to $\sigma_{h}$. Passing $\sigma_{h}$, the value of the bank starts to fall in relation to the value with subordinated debts, until it starts to suffer from financial difficulties, in $\bar{\sigma}$.

$\sigma_{l}=\sigma_{h}=\bar{\sigma}-$ CEF and Citibank: high risk in non regulated environments, being at the limit of financial difficulties, that is, in an environment with well defined regulation, these banks would have an optimal structure and maximum return. However, if the regulation ceases to exist, these banks would be at the limit and become insol- vent and without room to increase their risks.

$\sigma_{l}<\sigma_{h}=\bar{\sigma}-$ Bradesco and BTG Pactual: low risk in non regulated environments, and where risk may increase in search of greater returns. However, if the value of subordinated debts equals the value of CoCos, they would be at the limit and become insolvent and without room to increase their risks.

$\sigma_{l}=\sigma_{h}<\bar{\sigma}-$ HSBC and Safra: high risk in non regulated environments, but not yet suffering financial difficulties, that is, there is no advantage in increasing risk.

$\sigma_{l}=\sigma_{h}<N D$ - For Votorantim it was not possible to estimate the $\bar{\sigma}$. Thus, it could be considered in the group $\sigma_{l}$ $=\sigma_{h}=\bar{\sigma}$, given that the values are very close.

The results of the Koziol and Lawrenz (2012) model with the assumptions used suggest that BB, Itaú Unibanco, Santander, Bradesco, BTG Pactual, HSBC, and Citibank would have a preference and incentives to take more risk $\left(\frac{\partial S_{t}^{c}}{\partial \sigma}>0\right.$ e $\xi$ $<$ critical $\hat{\xi}$ ), but only BB, Itaú Unibanco, Santander, Bradesco, BTG Pactual, and HSBC $\left(\sigma_{l}<\sigma_{h}<\bar{\sigma}\right.$ e $\left.\sigma_{l}=\sigma_{h}<\bar{\sigma}\right)$ would have room to, in fact, increase risk. Citibank, despite the preferences and incentives, does not have any room to increase risk in environments without regulation $\left(\sigma_{l}=\sigma_{h}=\bar{\sigma}\right)$. CEF, Votorantim, and Safra do not have preferences or incentives for risk $\left(\frac{\partial \mathrm{s}_{\mathrm{c}}^{\mathrm{c}}}{\partial \sigma}<0 \mathrm{e} \xi<\right.$ critical $\left.\hat{\xi}\right)$ and are in situations that do not favor this increase $\left(\sigma_{l}=\sigma_{h}=\bar{\sigma} e \sigma_{l}=\sigma_{h}<\bar{\sigma}\right)$.

Difference in the probabilities of insolvency $\left(\Delta P_{T}\right)$ : analyzing the difference between the probabilities of insolvency in risks $\sigma_{1}$ and $\bar{\sigma}$, all of the banks exhibited a negative result or one equal to zero, so that no bank is in the insolvency band.

Thus, from the Koziol and Lawrenz (2012) model and with the assumptions used, all of the banks exhibited results within those expected, so that such results are compatible with Proposals 1, 2, and 3.

\section{CONCLUSION}

The Koziol and Lzwrenz (2012) model was applied to the 10 biggest Brazilian banks in terms of total assets with the National Financial System and, taking into account the new level I defined by BACEN - composed not only of share capital, but of CoCos of additional capital and countercyclical capital, in which the conversion threshold of these is defined as $4.5 \%$ of RWA - we endeavored to find out whether at the close of 2013 (4Q2013) these banks would be better capitalized with Cocos than with subordinated debts.

From the model, these banks, in fact, would be better capitalized with CoCos than with subordinated debts. However, thinking of efficiency, there may be a better optimized capital structure composed of CoCos and subordinated debts, but this model does not allow this type of structure to be tested. Moreover, this study analyzes capital structure at a specific moment; however, the model allows cash flows to be projected simulating economic cycles, which would allow it to be tested whether, in fact, the Basel III regulation is efficient in cases of crises that are very close, in which the recapitalization time for the bank would be short. However, that would be the subject of an upcoming study. 


\section{References}

Albul, B., Jaffee, D. M., \& Tchistyi, A. (2010). Contingent convertible bonds and capital structure decisions. Coleman Fung Risk Management Research Center. Working paper, Haas School of Business, University of California at Berkeley.

Andrade, G., \& Kaplan, S. N. (1998). How costly is financial (not economic) distress? Evidence from highly leveraged transactions that became distressed. The Journal of Finance, 53(5), 1443-1493.

Bank, M., \& Lawrenz, J. (2010). Deposit finance as a commitment device and the optimal debt structure of commercial banks. European Financial Management.

Barucci, E., \& Del Viva, L. (2012). Countercyclical contingent capital. Journal of Banking \& Finance 36(6), 1688-1709.

BCBS, Bașel Committee on Banking Supervision. (1988, July). Basel Committee: International convergence of capital measurement and capital standards. Retrieved from $<\mathrm{http} / /$ www.bis.org/publ/bcbs04a. pdf>.

Bhattacharya, S., Plank, M., Strobl, G., \& Zechner, J. (2002). Bank capital regulation with random audits. Journal of Economic Dynamics and Control, 26(7), 1301-1321.

Basel III. (2010). A global regulatory framework for more resilient banks and banking systems. Bank for International Settlements, revised version June 2011: Retrieved from: <http://www.bis.org/publ/bcbs189.pdf > .

Basel III. (2013). The liquidity coverage ratio and liquidity risk monitoring tools. Bank for International Settlements. Available at: $<$ http://www.bis. org/publ/bcbs238.pdf>.

Bollen, N. P. B. (1997). Derivatives and the price of risk. Journal of Futures Markets, 17(7), 839-854.

Bulow, J. I., \& Shoven, J. B. (1978). The bankruptcy decision. The Bell Journal of Economics, 437-456.

Calomiris, C. W., \& Herring, R. J. (2011). Why and how to design a contingent convertible debt requirement. Available at SSRN 1815406.

Dam, L., \& Koetter, M. (2012). Bank bailouts and moral hazard: Evidence from Germany. Review of. Financial Studies, 25(8), 2343-2380.

Decamps, J. P., Rochet, J. C., \& Roger, B. (2004). The three pillars of Basel II: optimizing the mix. Journal of Financial Intermediation, 13(2), 132-155.
Flannery, M. J., \& Rangan, K. P. (2008). What caused the bank capital buildup of the 1990s? Review of Finance, 12(2), 391-429.

Flannery, M. J. (2005). No pain, no gain? Effecting market discipline via "reverse convertible debentures". In H. S. Scott (Ed.); Capital Adequacy Beyond Basel: Banking, Securities, and Insurance (pp .171-196). Oxford University Press.

Glasserman, P., \& Nouri, B. (2012). Contingent capital with a capital-ratio trigger. Management Science, 58(10), 1816-1833.

Guidara, A., Soumaré, I., \& Tchana, F. T. (2013): Banks' capital buffer, risk and performance in the Canadian banking system: Impact of business cycles and regulatory changes. Journal of Banking \& Finance, 37(9), 3373-3387.

International Convergence of Capital Measurement and Capital Standards: A Revised Framework. (2006, June). Comprehensive Version. Retrieved from <http://www.bis.org/publ/bcbs128.pdf>.

Koziol, C., \& Lawrenz, J. (2012). Contingent convertibles. Solving or seeding the next banking crisis? Journal of Banking \& Finance, 36(1), 90-104.

Kuritzkes, A., \& Scott, H. (2009). Markets are the best judge of bank capital. Financial Times.

Oliveira, R. F., Schiozer, R. F., \& Barros, L. A. B. C. (2015). Depositors' Perception of "Too-Big-to-Fail". Review of Finance, 19(2), 191-227. Doi: 10.1093/rof/rft057.

Pennacchi, G. (2010). A structural model of contingent bank capital. Working paper, University of Illinois at Urbana-Champaign.

Peura, S., \& Keppo J. (2005). Optimal bank capital with costly recapitalization AFA 2005 Philadelphia Meetings.

Sobreira, R., \& Silva, T. G. (2012). Basel III and Brazilian Banks. Associação Keynesiana Brasileira.

Sundaresan, S., \& Wang, Z. (2014). On the design of contingent capital with a market trigger. The Journal of Finance, 70(2), 881-920.

Teixeira, J. C., Silva, F. J., Fernandes, A. V., \& Alves, A. C. (2013). Banks' Capital, Regulation and the Financial Crisis. Regulation and the Financial Crisis (December 18, 2013).

VanHoose, D. (2007). Theories of bank behavior under capital regulation. Journal of Banking \& Finance, 31(12), 3680-3697.

\section{Correspondence Address:}

Karina Cyganczuk Goes

Fundação Getúlio Vargas

Avenida 9 de Julho, 2029 - CEP: 01313-902

Bela Vista - São Paulo - SP

Email: karina.goes@gvmail.br 